\title{
REVITALISASI PERAN SOSIAL SURAU DAGANG DALAM PEMBENTUKKAN KARAKTER MASYARAKAT PASAR TRADISIONAL DI PADANG PARIAMAN
}

\author{
Yusrizal Effendi \\ Fakultas Ushuluddin Adab dan Dakwah LAIN Batusangkar \\ E-mail:yusrizalefendi@yahoo.com \\ Nofri Andy N \\ Fakultas Ushuluddin Adab dan Dakwah LAIN Bukittinggi \\ E-mail:nofri_andi@yahoo.com
}

\begin{tabular}{l|l|l} 
Diterima : 23 April 2018 & Direvisi : 30 Mei 2018 & Diterbitkan : 30 Juni 2018
\end{tabular}

\begin{abstract}
Term surau sangat identik dengan masyarakat Minang dan usianya hampir sama dengan terjadinya Islamisasi di Sumatera Barat. Surau masih eksis hingga saat ini karena kegunaannya yang multi fungsi. Menurut Elizabeth E. Graves, setelah anak muda mengalami pubertas, pemuda tidak dapat lagi tidur di rumah orangtuanya, tetapi tidur di surau bersama teman sebaya yang lain. Pelajar yang pergi meninggalkan nagari, guru-guru agama serta para pedagang yang datang dari daerah yang jaub menjadikan surau sebagai tempat peristirabatan. Belakangan fungsi surau, terutama surau dagang tidak berbanding lurus dengan niat pendiri sebelumnya. Surau dagang banyak ditinggalkan karena paradigmanya hanya dijadikan sebagai tempat persinggahan bagi saudagar yang datang dari jauh. Dalam penelitian ini, penulis mengemukakan perlunya revitalisasi surau dagang secara fungsional sebagai khazanah pembentukan karakter pemuda Minang dalam menempa kehidupan. Temuan yang penulis dapatkan dari penelitian ini adalah beberapa suran di Pasar Tradisional seperti Balai Pauh Kambar, Sungai Sariak, dan sebagainya ternyata masib aktif melakukan kegiatan-kegiatan keagamaan yang dapat membendung masuknya paham-paham radikal di Padang Pariaman.
\end{abstract}

Keywords: Peran Sosial, Surau Dagang, Pasar Tradisional

\begin{abstract}
Abstrak
Term surau sangat identik dengan masyarakat Minang dan usianya hampir sama dengan terjadinya Islamisasi di Sumatera Barat. Surau masib eksis hingga saat ini karena kegunaannya yang multi fungsi. Menurut Elizabeth E. Graves, setelah anak muda mengalami pubertas, pemuda tidak dapat lagi tidur di rumah orangtuanya, tetapi tidur di surau bersama teman sebaya yang lain. Pelajar yang pergi meningsalkan nagari, guru-guru agama serta para pedagang yang datang dari daerah yang jauh menjadikan surau sebagai tempat peristirahatan. Belakangan fungsi surau, terutama surau dagang tidak berbanding lurus dengan niat pendiri sebelumnya. Surau dagang banyak ditinggalkan karena paradigmanya hanya dijadikan sebagai tempat persinggahan bagi saudagar yang datang dari jauh. Dalam penelitian ini, penulis mengemukakan perlunya revitalisasi surau dagang secara fungsional sebagai khazanah pembentukan karakter pemuda Minang dalam menempa kehidupan. Temuan yang penulis dapatkan dari penelitian ini adalah beberapa surau di Pasar Tradisional seperti Balai Pauh Kambar, Sungai Sariak, dan sebagainya ternyata masih aktif melakukan kegiatan-kegiatan keagamaan yang dapat membendung masuknya paham-paham radikal di Padang Pariaman.
\end{abstract}

Kata Kunci: Peran Sosial, Surau Dagang, Pasar Tradisional 


\section{Latar Belakang}

Surau ${ }^{1}$ merupakan istilah yang identik dengan masyarakat Minang, usianya hampir sama dengan proses terjadinya Islamisasi di Sumatera Barat. Eksistensi surau hingga saat ini masih dipertahankan karena kegunaannya yang multi fungsi. Menurut Elizabeth E. Graves, setelah anak muda mengalami pubertas, pemuda tidak dapat lagi tidur di rumah orangtuanya, tetapi tidur di surau bersama teman sebaya yang lain. Pelajar yang pergi meninggalkan nagari, guru-guru agama serta para pedagang yang datang dari daerah yang jauh menjadikan surau sebagai tempat peristirahatan. $^{2}$

Di Minangkabau, anak laki-laki tidak mendapatkan fasilitas kamar di rumahnya sehingga dia harus hijrah ke surau, hal ini merupakan sikap mengalah dan memuliakan bagi saudara perempuan. Fungsi surau pada masa dahulunya berkaitan dengan sekolah sosial yang mengajarkan anak muda untuk berproses serta memiliki jiwa solidaritas yang tinggi dan mandiri sehingga terbiasa untuk tidak selalu menggantungkan hidup kepada orang tua.

Aspek penting lain mengenai keberadaan surau bagi masyarakat pedesaan minangkabau antara lain dijadikannya surau sebagai pusat penyebaran dan perkembangan Islam ke daerah-daerah Sumatera Barat.

${ }^{1}$ Dalam tradisi di Minangkabau anak yang berusia 6-7 tahun sudah diwajibkan untuk tidur di surau. Kegiatan ini dimulai dengan shalat magrib berjamaah, kemudian dilanjutkan dengan mengaji dan mendalami ilmu agama Islam yang diajarkan oleh ulama kampung. Di samping diajarkan ilmu agama, mereka juga diberi bekali pengetahuan tentang akhlak serta pengalaman untuk menghadapi masa yang akan datang. Setelah melaksanakan shalat Isya berjamaah, pemuda tersebut diajarkan tafsr serta pencak silat kemudian istirahat tidur. (Ake Nera Atakiwang, dkk., Tanjung Mata Bulan Antologi Puisi Esai Menarik (Depok: Jurnal Sajak Indonesia, 2014), 57.

2 Elizabeth E. Graves, Asal Usul Elite Minangkabau Modern: Respon terbadap Kolonial Belanda Abad XIX/XX terj. Novi Andri, dkk. (Jakarta: Yayasan Obor Indonesia, 2007), 41.
Seperti halnya di Pulau Jawa surau juga digunakan sebagai akses bagi Islamisasi yang intensif di daerah-daerah terpencil dari pelabuhan pantai barat minangkabau yang telah terislamkan sejak dekade kedua abad XVI bersamaan keterlibatan mereka dalam perdagangan internasional. Surau juga menciptakan kondisi-kondisi yang mendukung interaksi mendalam dan hubungan yang dekat antara Islam dan masyarakat minangkabau. ${ }^{3}$

Marthias Dusky Pandoe sebagai jurnalis senior menilai bahwa ada beberapa jenis surau, di antaranya surau kaum atau suku yang berfungsi sebagai tempat mengaji dan shalat berjamaah bagi anggota suku. Lazimnya setiap suku memiliki guru mengaji yang piawai, cakap menjadi imam, dan terkadang sanggup untuk memberikan siraman rohani bagi para anggotanya. Surau juga dapat digunakan sebagai ajang untuk mempererat hubungan silaturrahim keluarga besar. Dua fungsi surau yang paling fundamental adalah sebagai sarana pendidikan dan juga tempat untuk melaksanakan ibadah. Surau merupakan fondasi dalam penegakkan falsafah Adat Basandi Syara', Syara' Basandi Kitabullah (ABS-SBK), ranah belumlah dikatakan lengkap apabila belum memiliki surau. ${ }^{4}$

Orang Minang dikenal dengan orang yang kuat dalam memegang teguh agama dan adat. Sehingga dimanapun berada mereka akan menyesuaikan tempat keberadaan tersebut seperti apa yang di dapat di daerahnya. Hal ini terlihat dalam masyarakat Minang yang ada di perantauan atau di kampung namun berpindah ke kampung yang lain. Membangun surau dari swadaya bersama merupakan kebanggaan tersendiri bagi orang Minang dalam mendukung usaha serta upaya dalam

3 Jajat Burhanuddin, Ulama dan Kekuasaan: Pergumulan Elit Muslim dalam Sejarah Indonesia (Jakarta: Mizan Publika, 2012), 87.

${ }^{4}$ Marthias Dusky Pandoe, Jernih Melihat Cermat Mencatat: Antologi Karya Jurnalistik Wartawan Senior Kompas (Jakarta: Kompas, 2010), 253. 
peningkatan nilai-nilai keagamaan. Surau di sini tidak hanya dipahami sebagai tempat shalat semata tetapi dilengkapi oleh perangkatperangkat yang lain, seperti tuanku, anak murid mengaji, jamaah yang setia untuk melaksanakan wirid mingguan, dan jamaah tetap dalam melaksanakan shalat lima waktu sehari semalam.

Berdagang merupakan profesi yang kerap dilakukan oleh orang Minang. Hal ini lebih disebabkan minimnya sumber daya alam yang ada di kampung dan jiwa merdeka yang dimiliki seorang pedagang. Surau dagang yang didirikan oleh urang dagang pada masa lalu memberikan dampak yang kuat bagi religiusitas pedagang ketika itu, karena posisi sebagai orang rantau dan berdomisili di surau untuk sementara menjadikan mereka hati-hati dalam berperilaku dan bersikap jujur. Dalam riset ini, peneliti akan mengkaji peran sosial surau dagang yang terdapat di pasar tradisional Padang Pariaman dan program-program surau dalam mewujudkan peranan sosial yang berarti bagi pedagang dan masyarakat dan bagaiamana dampak program tersebut bagi masyarakat.

\section{Metode}

Penelitian ini menggunakan metode kualitatif dengan pendekatan fenomenologi, yaitu pendekatan yang akan mengungkap fenomena yang terjadi mengenai peran sosial surau dagang di pasar tradisional serta dampak dari kegiatan-kegiatan surau bagi pedagang dan masyarakat. Teknik pegumpulan data yang digunakan adalah pengamatan terlibat (participant obsesrvation), wawancara mendalam, dan studi data sekunder. Pengamatan terlibat dilakukan pada latar alamiah (tak terstruktur). Data yang telah terkumpul dianalisis secara kualitatif dengan menggunakan langkahlangkah: (1) pengumpulan data, (2) interpretasi data, dan (3) penulisan laporan.

\section{Dinamika Surau dalam Ranah Sosial di Minangkabau}

Surau berasal dari bahasa Arab Sugra berarti kecil, karena pengaruh dialek kata ini berubah menjadi surau yang berarti bangunan lebih kecil dari masjid didirikan sebagai pelengkap rumah gadang. Surau biasanya dibangun dekat dengan sumber air, karena diharapan nanti akan ada pemukiman baru, kegiatan dagang dan pasar baru serta peradaban baru. Jaringan surau juga dapat dijadikan sebagai penghubung dengan jaringan pasar dan ekonomi strategis di Minang, seperti jaringan desa pertanian, desa pertambangan dan desa yang terletak pada rute-rute perdagangan. ${ }^{5}$ Surau juga dapat dijadikan sebagai pusat informasi bagi para pedagang mengenai daerah yang ramai pembeli dan sebagai tempat untuk mempersiapkan strategi untuk berdagang.

Peran surau sebagai lembaga pendidikan agama pertama di Sumatera Barat sangat dibutuhkan, selain berfungsi tempat belajar juga digunakan sebagai tempat tinggal bagi guru dan murid. Sistem ini memungkinkan guru dan murid berada dalam lokasi yang sama dalam waktu yang panjang. Di sana tercipta proses pembelajaran antara guru dan murid sehingga regenerasi ulama berlangsung secara alami. Surau yang pertama didirikan adalah surau Syekh Burhanuddin Ulakan yang didirikan sekitar abad XVII, surau ini didatangi oleh berbagai murid dari pelosok Minangkabau. ${ }^{6}$

Eksistensi surau sebagai sebauh institusi yang merupakan ciri khas Sumatera Barat telah menandakan bahwa orang Minang telah memiliki headstart lebih awal dalam bidang pendidikan dan hal ini berimbas kepada bidang-bidang yang lain seperti pergerakan dan politik. Hal membuktikan bahwa orang Minang lebih maju dibandingkan

5 Ahmad Baso," Surau: Pusat Dakwah di Minangkabau", http://www.nu.or.id diakses pada Selasa, 14 Maret 2017 pukul 23.00 WIB.

${ }^{6}$ Azizah Etek, ddk., Koto Gadang Masa Kolonial (Yogyakarta: LkiS, 2007), 109. 
dengan etnis-etnis lain yang masih diam dan terbelakang. Terutama pada awal abad XX hingga dasawarsa pertama pasca proklamasi ketika berbicara tentang pergerakan nasional, dalam tarikan napas yang sama ditemukan nama-nama seperti H. Agus Salim, Mohammad Hatta, Sutan Sjahrir bersama tokoh seperti Soekarno. Dalam dua atau tiga dasawarsa pasca proklamasi semakin banyak kalangan-kalangan etnis lain mencapai mobilitas dan ketokohan pada tingkat nasional, sedangkan etnis Minang mengalami stagnan. ${ }^{7}$

Mesranya hubungan masyarakat dan surau didukung oleh maraknya pemahaman sufisme di daerah-daerah pedalaman Minangkabau. Sehingga ajaran dan praktek Islam di surau-surau dengan mudah disesuaikan dengan adat lokal dan menawarkan semangat yang dekat dengan sistem budaya kaum petani di desa-desa Minangkabau. Surau juga menoleransi budaya pra-Islam yang begitu mengakar di kalangan Muslim Minang serta surau menawarkan gagasan dan praktek yang sesuai dengan ritme kehidupan masyarakat petani ketika itu. Oleh sebab itu, kondisi ini berbeda dengan Islam yang telah mapan di daerah pelabuhan dagang, daerah terluar (rantau), perkembangan Islam di daerah lebih fokus kepada menjaga budaya masyarakat desa. ${ }^{8}$

Ranah Minang yang dikenal sebagai daerah yang kuat dalam mengamalkan ajaran agama pernah menjadi ruang kontestasi antara kelompok pembaharu dan tradisional. Hal ini meninggalkan bekas yang begitu mendalam bagi generasi berikutnya di antaranya munculnya semangat kritis dalam beragama sehingga kerap menimbulkan geseskan di kalangan masyarakat. Fenomena ini terjadi

7 Azyumardi Azra "Mambangkik Batang Tarandam: Wacana dan Praksis Revitalisasi Minang" dalam Reinventing Indonesia: Menemukan Kembali Masa Depan Bangsa, Komaruddin Hidayat \& Putut Widjanarko (ed.), (Jakarta: Mizan 2008), 557.

${ }^{8}$ Jajat Burhanuddin, Ulama dan Kekuasaan, loc. cit. ketika gelombang pembaharuan Islam di Minangkabau pada akhir abad XVIII yang dibawa oleh pengikut tarekat di Timur Tengah, anak benua India dan diperkuat lagi dengan terbukanya hubungan Makkah dan Madinah. Pembaharuan ini lebih kepada penguatan syariah, sedangkan di kalangan Syattariyah juga digalakkan usaha ke arah tersebut dengan mendalami al-Qur'an, Fiqh, dan Hadis di kelembagaan surau. ${ }^{9}$

Puncak dari konflik tersebut adalah munculnya murid Tuanku Nan Tuo, seperti Haji Miskin, Tuanku Nan Renceh, Imam Bonjol, Haji Sumanik, dan Haji Piobang yang terpengaruh oleh metode wahabi yang sedang berkembang di Arabia. Mereka menyerang surau-surau yang dianggap telah melakukan praktek tahayul dan khurafat sehingga pecahlah perang antara kelompok radikal dan moderat yang merupakan cikal bakal dari perang Paderi pada tahun 1821-1837 ketika Belanda sudah ikut campur tangan. ${ }^{10}$

Diskusi mengenai surau di Minangkabau dapat dihubungkan dengan analisis Max Weber dalam karyanya, The Protestant Ethic and the Spirit of Capitalisme tentang epistemik ethos menjelaskan adanya hubungan dimensi spritual (agama atau ideologi, ethos), pendidikan dengan semangat ekonomi perdagangan (entrepreneur). Tiga komponen ini merupakan karakteristik yang selalu melekat bagi warga Minang baik yang ada di kampung maupun di perantauan. Mereka tidak bisa memisahkan hidupnya dari agama dan adat serta akan marah apabila dikatakan "tidak beradat" atau "tidak beragama". Posisi adat dan agama merupakan suatu kesatuan yang saling menguatkan dalam mewujudkan filosofi adat Minangkabau.

9 Azyumardi Azra, Surau; Pendidikan Islam Tradisional dalam Transisi dan Modernisasi (Jakarta: Logos Wacana Ilmu, 2003), 120.

10 Meimunah S. Moenada, "Surau dan Modernisasi Pendidikan di Masa Hindia Belanda", Jurnal Sosial Budaya, Vol. 8 No. 01, (2011), 43. 


\section{Memahami Konsep Revitalisasi Peran Sosial Untuk Mewujudkan Kembali Eksistensi Surau}

Revitalisasi dapat dipahami sebagai bentuk perubahan (transformasi) yang mengandung proses penguatan yang meliputi peneguhan terhadap aspek-aspek yang selama ini dimiliki (proses potensial) maupun dengan melakukan pengembangan (proses aktual) menuju keadaan yang lebih baik dan lebih maju dari kondisi sebelumnya. Dalam implementasinya, revitalisasi memiliki tahapantahapan yang meliputi: penataan, pemantapan, peningkatan dan pengembangan yang dilakukan secara berkesinambungan.

Maraknya surau dagang yang ada di pasar tradisional merupakan suatu hal yang menarik untuk dikaji, karena pada masa lalu peran surau sangat kentara dirasakan baik sebagai lembaga pendidikan maupun sebagai tempat istirahat bagi masyarakat dan para pedagang yang datang dari jauh. Seiring berkembangnya zaman, surau masih tetap eksis namun pemanfaatannya mengalami pengembangan, di antaranya sebagai tempat silaturahim dan lembaga sosial yang akan membantu meringankan beban masyarakat.

Di Minangkabau, kebudayaan dan pusat aktivitas masyarakat seringkali diadakan di surau. Sehingga dapat diklasifikan fungsi surau antara lain: tempat shalat, tempat mengaji, belajar agama, asrama bagi para siswa, tempat merayakan hari besar Islam, upacara keagamaan, tempat suluk, tempat bertemu, berkumpul, rapat, penginapan bagi musafir da sebagainya. Sehingga jelas fungsi masjid hanya digunakan untuk pelaksanaan shalat lima waktu dan dua hari raya sehingga kebersihan dan kenyaman tetap terjaga. ${ }^{11}$

${ }^{11}$ Muhammad Natsir Yunas, "Peran Surau Syekh Burhanuddin sebagai Lembaga Pendidikan Islam Tradisional di Pariaman Sumatera Barat", Jurnal Penelitian dan Evaluasi Pendidikan, No. 2, (2005), 211.
Di tahun 2000 pakar pendidikan Barat menggulirkan konsep kecakapan hidup (life skill) dan didukung oleh pakar pendidikan di Indonesia agar diterapkan di sekolah-sekolah. Intinya, kecakapan ini berisi tentang sebuah pola atau konsep dimana seorang peserta didik dituntut untuk menemukan kecakapan hidup melalui proses pembelajaran yang dilalui di sekolah. Kecakapan hidup tersebut, antara lain: eksistensi diri, kecakapan adaptasi, kecakapan komunkasi, kecakapan memilah masalah, kecakapan memilih masalah, kecakapan mengambil keputusan, kecakapan sosial, dan kecakapan personal. Semua model ini telah dikaji dan dipraktekkan oleh tokohtokoh Minang dan hasilnya telah ditunjukkan dengan posisi strategis yang dipegang pada saat ini. ${ }^{12}$

Surau yang merupakan pusat transformasi keilmuan di Minangkabau sebenarnya dimulai dari kaum keluarga sehingga muncul ungkapan dari ninik turun ke mamak, dari mamak turun ke kamanakan". Maka konstruksi lembaga surau terdiri dari mamak sebagai guru, kemenakan sebagai murid, surau sebagai sarana, dan bahan ajarnya adalah nilainilai yang dianggap berguna untuk bekal hidup bagi generasi di masa mendatang. Dalam proses perjalanan waktu melalui pengayaan kultural nasional dan internasional terjadi degradasi peran dan fungsi surau sebagai sebatas rumah ibadah untuk kemudian menjadi surau tua yang tersisih di sudut-sudut dusun. Orang lupa akan jasa surau sebagai sarana transformasi nilai yang begitu dalam meninggalkan jejak sejarahnya.

Peran merupakan sejumlah tindakan yang dilakukan individu dalam suatu konteks (lingkungan). Peran akan efektif apabila memenuhi beberapa syarat yang didalamnya

12 Achjar Chalil, "Peranan Surau dalam Pembentukan Karakter Masyarakat Minangkabau, https://enewsletterdisdik.wordpress.com diakses pada 15 Oktober 2017. 
terdapat norma yang melekat pada posisi sosial pelaku, kepercayaan/agama dan sikap yang dianut, serta konsep peran yang dimainkan.

Dalam mengkaji peran surau dagang ini, peneliti menggunakan pendekatan fungsional yang terapkan oleh Talcott Parsons yang menjelaskan masyarakat sebagai suatu sistem memiliki struktur yang terdiri dari banyak lembaga, dimana masing-masing lembaga memiliki fungsi sendiri-sendiri. Struktur dan fungsi dengan kompleksitas yang berbeda-beda ada pada setiap masyarakat, baik masyarakat modern maupun masyarakat primitif. Misalnya lembaga sekolah yang berfungsi mewariskan nilai-nilai yang ada kepada generasi baru, lembaga keagamaan yang berfungsi membimbing pemeluknya menjadi anggota masyarakat yang baik dan penuh pengabdian untuk mencapai kebahagiaan dunia dan akhirat.

Dalam merealisasikan teorinya, Talcott menggunakan paradigma AGIL (Adaptation, Goal-Attainment, Latent-Pattern-Maintenance) yang menitikberatkan pada kehidupan sosial sebagai suatu sistem sosial memerlukan terjadinya ketergantungan yang berimbas pada stabilitas sosial. AGIL merupakan singkatan dari:

Adaptation yaitu kemampuan masyarakat untuk berinteraksi dengan lingkungan alam. Hal ini berhubungan dengan usaha mengumpulkan sumber-sumber kehidupan serta menghasilkan komoditas untuk redistribusi sosial.

Goal-Attainment adalah kecakapan untuk mengatur dan menyusun tujuan-tujuan masa depan dan membuat keputusan yang sesuai dengan permasalahan yang dihadapi

$$
\text { Integration atau harmonisasi }
$$

keseluruhan anggota sebagi sistem sosial setelah kesepakatan mengenai nilai-nilai atau pada masyarakat ditetapkan.

Latency (Latent-Pattern-Maintenance) adalah memelihara sebuah pola, dalam hal ini nilai-nilai kemasyarakatan tertentu, seperti budaya, norma, aturan, dan sebagainya.

\section{Peran Surau Dagang dalam Pembentukkan Karakteristik Masyarakat Pasar Tradisional}

Menurut Buya Mas'oed Abidin berdagang bagi masyarakat Minang merupakan profesi yang lazim, bahkan orang Minang seringkali diidentikkan dengan profesi ini. Di Minangkabau kata dagang memiliki makna yang mendalam dan mencakup filosofi hidup sebagai bagian dari identitas budaya. Dagang tidak hanya berari bisnis an sich, kata ini juga mengandung makna merantau dengan tujuan mencari bekal untuk kehidupan baik dalam jangka pendek maupun jangka panjang. Bagi masyarakat Minang anak dagang bukanlah orang buangan, bahkan dia sangat dihormati dan memiliki hak-hak tertentu. Mereka juga dibuatkan surau dagang untuk menginap dalam beberapa waktu. Penilaian masyarakat tidak terbatas kepada negeri asal anak dagang, namun lebih kepada kebaikan perilakunya bahkan kerap diambil menantu oleh warga setempat karena sikap tanggung jawab dan kemandirian yang telah dipraktekkan dalam kehidupan sehari-hari.

Padang Pariaman adalah kabupaten yang memiliki penduduk yang padat yaitu berjumlah 400.890 orang. ${ }^{13}$ Angka ini merupakan angka yang tinggi dibandingkan dengan kabupaten/kota yang lain, sehingga masyarakat dari daerah luar tertarik untuk berdagang di daerah ini, hal terbukti datangnya para pedagang dari Batusangkar, Padang Panjang, dan kota-kota yang lainnya. Meningkatnya laju pertumbuhan penduduk menurut Simon (1982) adalah sebagai modal bagi pembangunan ekonomi. Ia juga menambahkan bahwa penduduk yang besar

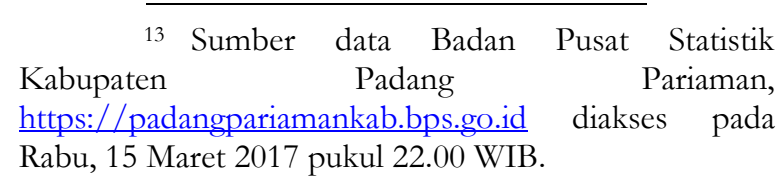


bukanlah suatu beban. Semakin besar jumlah penduduk di suatu daerah akan menjadikan permintaan meningkat, sehingga akan terjadi economic of scale (keuntungan yang berlipat) dalam produksi.

Pasar tradisiona ${ }^{14}$ masih diminati oleh masyarakat Padang Pariaman, karena harganya dapat dijangkau serta kebutuhan yang dicari oleh masyarakat tersedia dengan lengkap. Hingga saat ini pasar tradisional tetap eksis di 17 kecamatan yang ada di Padang Pariaman serta memilki hari balai tersendiri. Jalinur ${ }^{15}$ mengungkapkan bahwa hari balai bagi pasarpasar tersebut berbeda-beda, di antaranya:

a. Balai Akaik (ahad) di Pasar Sintuk kecamatan Sintuk Toboh Gadang

b. Balai Sanayan (Senin) dan Jum'at di Pasar Sicincin kecamatan $2 \times 11$ Sicincin

c. Balai Selasa di Pasar Lubuk Alung kecamatan Lubuk Alung

d. Balai Raba'a (Rabu) di pasar Sungai Sariak kecamatan VII koto Sungai Sariak

e. Pasar Kamis di Pasar Pakandangan kecamatan Enam Lingkung

f. Pasar Sabtu di Pasar Pauh Kambar di kecamatan Nan Sabaris

Dalam menghadapi modernisasi, peran surau juga mengalami perkembangan yang sesuai dengan zaman. Hal ini juga terlihat dari surau dagang Pasar Pauh Kambar dimana pada dahulunya para pedagang datang dari daerah yang jauh, namun seiring dengan perkembangan zaman para perantau tersebut

${ }^{14} \mathrm{Di}$ antara ciri-ciri pasar tradisional adalah adanya hubungan antara pedagang dengan pembeli secara langsung, transaksi terjadi secara spontan serta adanya tawar menawar harga dengan transparan. Karakteristik tersebut hingga sekarang masih dimiliki oleh pasar nagari yang dimiliki oleh nagari-nagari di Sumatera Barat sebagai kesatuan wilayah hukum adat, hal ini ditandai dengan adanya nagari sebagai wilayah otonom yang memiliki harta kekayaan. (Irchami Sulaiman, Perdagangan Usaha Cina: Perilaku Pasar (Jakarta: Grafika, 1998), 7.

${ }^{15}$ Wawancara dengan Jalinur, warga Pakandangan pada Senin, 13 Maret 2017 pukul 09.00 WIB. telah membeli tanah dan menetap di sana serta tetap dengan mempertahankan surau mereka dengan ciri khas surau dagang masa lalu. ${ }^{16}$

Melihat perubahan yang menonjol dalam fungsi surau, Azra mengungkapkan surau memang tidak lagi menjadi kamar bagi anak laki-laki atau tempat tinggal bagi suami yang telah ditinggal mati oleh istrinya serta sebagai tempat bermalam bagi para pedagang keliling (babelok), namun eksistensinya masih dibutuhkan dalam upaya transmisi nilai-nilai dasar keagamaan dan adat istiadat Minangkabau. ${ }^{17}$

Pada awal 1980-an perkembangan kehidupan beragama semakin meningkat, hal ini ditandai dengan meningkatnya jumlah rumah ibadah, jemaah haji juga mengalami masa tunggu yang lama, dan umat Islam semakin giat dalam menjalankan ibadahnya. Meskipun peningkatan ini seringkali bersifat simbolis tanpa diikuti dengan hal-hal yang subtantif yang akan berdampak kepada munculnya sikap keshalehan sosial. ${ }^{18}$ Sikap ini juga berdampak kepada para pedagang sehingga mereka tidak segan-segan untuk menyedekahkan sebagaian harta mereka. Hal ini dapat dilihat dari beberapa surau dagang yang didirikan dengan bangunan yang megah.

Pemerintah Sumatera Barat juga memberikan dukungan yang positif mengenai pentingnya surau, di antaranya dengan ditetapkan Perda No. 9 tahun 2000 tentang pokok-pokok pemerintahan nagari yang memasukkan Surau sebagai bagian dari harta kekayaan nagari (Pasal 7) sebagai sebagai upaya

${ }^{16}$ Wawancara dengan Tk. Ilham Sikumbang, ulama Pasar Pauh Kambar pada Rabu, 1 Maret 2017 pukul 17.00 WIB.

17 Azyumardi Azra, "Mambangkik Batang Tarandam: Wacana dan Praksis Revitalisasi Minang" dalam Reinventing Indonesia: Menemukan Kembali Masa Depan Bangsa Komaruddin Hidayat \& Putu Widjanarko (Jakarta: Mizan, 2008), 573.

18 Tim Ditjenbud, Strategi Pembinaan dan Pengembangan Kebudayaan Indonesia (Departemen Pendidikan Nasional, 2000), 28. 
melestarikan tradisi minang. Hal tersebut merupakan upaya untuk mengembalikan fungsi surau sebagai proses pembinaan ilmu pengetahuan, mental, dan karaker generasi muda. Dengan adanya perda tersebut diharapkan para pemuda dapat meresapi nilainilai budaya yang kental hubungannya antara agama dan adat.

Pemahaman terhadap keagamaan dapat mempengaruhi seseorang dalam bersikap terhadap profesinya, begitu juga terhadap para pedagang. Pedagang yang banyak mendalami ilmu agama dalam melakukan transaksi akan menerapkan nilainilai kejujuran serta secara tidak langsung merupakan bagian dakwah dalam kehidupannya. Karena keterbatasan waktu, pedagang hanya bisa menambah pengetahuan mengenai agama di surau-surau pasar tradisional. ${ }^{19}$

Banyaknya didapati surau-surau di pasar tradisional, seperti Pasar Sicincin mengindikasikan bahwa semangat untuk beribadah dan menimba ilmu bagi pedagang masih ada walaupun diliputi oleh kesibukan. Dengan adanya perkembangan zaman dan proses modernisasi, maka penulis tertarik untuk meneliti bagaimana peran sosial yang terdapat di pasar tradisional dalam konteks kekinian.

\section{Kesimpulan}

Dari uraian di atas dapat ditarik kesimpulan sebagai berikut: pertama, Masyarakat Minang adalah kelompok masyarakat yang memegang filososi Adat Basandi Syara', Syara' Basandi Kitabullah (ABS-SBK) prinsip ini diimplementasikan dalam kehidupan sehari-hari dengan mengkolaborasikan antara nilai spritual, pendidikan, dan ekonomi sehingga dimanapun

\footnotetext{
${ }^{19}$ Wawacara dengan Anas, pedagang Pasar Pakandangan pada Kamis, 2 Maret 2017 pukul 14.00 WIB.
}

mereka berada maka ciri khas ini tidak akan hilang

Kedua, Peran surau dagang sangat signifikan dalam pembentukan karakteristik masyarakat Pasar Tradisional dan akan berpengaruh dalam kehidupan mereka seharihari, sehingga religius masyarakat menjadi terimbangi antara kepentingan dunia dan akhirat

Revitalisasi fisik Pasar Tradisional sangat penting, namun yang lebih penting adalah merivitaslisasi rohani orang-orang yang ada di pasar tersebut termasuk para pedagang dan masyarakat pasar tradisional terutama di Sumatera Barat yang masih memegang kuat nilai-nilai adat dan agama.

\section{Daftar Pustaka}

\section{Buku}

Adek Lestari, "Surau Masa Lalu Pada Masa Kini Luhak Agam (Orde) Baru" dalam Ruth Saiya, dkk., Ge(mer)lap Nasionalitas Postkolonial (Yogyakarta: Kanisius, 2008).

Atakiwang, Ake Nera, dkk.. Tanjung Mata Bulan Antologi Puisi Esai Menarik. Depok: Jurnal Sajak Indonesia, 2014.

Azra, Azyumardi Azra. "Mambangkik Batang Tarandam: Wacana dan Praksis Revitalisasi Minang" dalam Reinventing Indonesia: Menemukan Kembali Masa Depan Bangsa Komaruddin Hidayat \& Putu Widjanarko. Jakarta: Mizan, 2008.

Islam Tradisional dalam Transisi dan Modernisasi. Jakarta: Penerbit Logos, 2003.

Burhanuddin, Jajat. Ulama dan Kekuasaan: Pergumulan Elit Muslim dalam Sejarah Indonesia. Jakarta: Mizan Publika, 2012.

Graves, Elizabeth E.. Asal Usul Elite Minangkabau Modern: Respon terbadap Kolonial Belanda Abad XIX/XX terj. 
Novi Andri, dkk. Jakarta: Yayasan Obor Indonesia, 2007.

Kaelan. Metode Penelitian Kualitatif bidang Filsafat,

Paradigma bagi Pengembangan Penelitian Interdisipliner Bidang Filsafat, Budaya, Sosial, Semiotika, Sastra, Hukum, dan Seni. Yogyakarta: Paradigma, 2005.

Sulaiman, Irchami. Perdagangan Usaha Cina: Perilaku Pasar. Jakarta: Grafika, 1998.

Tim Ditjenbud. Strategi Pembinaan dan Pengembangan Kebudayaan Indonesia. Departemen Pendidikan Nasional, 2000.

\section{Jurnal}

Satria, Irwan. "Surau dalam Pengembangan Tradisi Minang di Daerah Perantau" Jurnal At-Ta'lim, Vol. XIV, No. 2, (2015)

Muhammad Natsir Yunas, "Peran Surau Syekh Burhanuddin sebagai Lembaga Pendidikan Islam Tradisional di Pariaman Sumatera Barat", Jurnal Penelitian dan Evaluasi Pendidikan, No. 2, (2005).

\section{Wawancara}

Wawancara dengan Jalinur, warga Pakandangan pada Senin, 13 Maret 2017 pukul 09.00 WIB.

Wawancara dengan Tk. Ilham Sikumbang, ulama Pasar Pauh Kambar pada Rabu, 1 Maret 2017 pukul 17.00 WIB.

Wawacara dengan Anas, pedagang Pasar Pakandangan pada Kamis, 2 Maret 2017 pukul 14.00 WIB.

\section{Website}

Baso, Ahmad," Surau: Pusat Dakwah di Minangkabau", http://www.nu.or.id diakses pada Selasa, 14 Maret 2017 pukul 23.00 WIB. Sumber data Badan Pusat Statistik Kabupaten Padang Pariaman, https://padangpariamankab.bps.go.id diakses pada Rabu, 15 Maret 2017 pukul 22.00 WIB. 